\title{
Study of BMP15 Gene Polymorphism in Boer, Kacang, and Boerka Goats
}

\author{
Batubara $\mathrm{A}^{1}$, Elieser $\mathrm{S}^{1}$, Sumantri $\mathrm{C}^{2}$ \\ ${ }^{1}$ Goats Research Station, PO BOX 1 Galang, Sei Putih 20585 - Indonesia \\ ${ }^{2}$ Faculty of Animal Science, Bogor Agricultural University, Jl. Agatis, Darmaga Campus, Bogor 16680 - Indonesia \\ E-mail: aronbatubara@gmail.com
}

(received 11-10-2016; revised 24-11-2016; accepted 05-12-2016)

\begin{abstract}
ABSTRAK
Batubara A, Elieser S, Sumantri C. 2016. Studi pada gen polimorfisme BMP15 pada kambing Boer, Kacang dan Boerka. JITV 21(4): 224-230. DOI: http://dx.doi.org/10.14334/jitv.v21i4.1636

Gen BMP15 atau sering disebut dengan FecX (fekunditas kromosom X) adalah gen yang mengatur sifat prolifik. Penelitian ini bertujuan untuk mengidentifikasi mutasi gen BMP15 dan menganalisa polimorfisme pada kambing Boer, Kacang dan Boerka. Kambing betina yang digunakan sebanyak 50 sampel, masing-masing 17 Boer, 16 Kacang dan 17 Boerka yang dianalisa keragaman genetiknya diidentifikasi menggunakan metode PCR-Sequencing. Amplifikasi gen BMP15 menghasilkan fragmen dengan panjang 141 bp. Penentuan genotipe gen BMP15 menghasilkan tiga genotipe. Hasil analisis menunjukkan bahwa pada gen BMP15 ditemukan 2 SNP polimorfik yang dianalisa berdasarkan frekuensi genotipe, frekuensi alel, heterozigositas dan uji keseimbangan Hardy-Weinberg ( $\chi 2$ ). Hasil sekuens fragmen gen BMP15 menunjukkan adanya mutasi antara basa adenin (A) dengan guanin (G) dan penentuan dari genotipe gen BMP15 ditemukan tiga genotipe yaitu GG, GA dan AA. Dapat disimpulkan bahwa telah ditemukannya identifikasi dari mutasi gen BMP15 pada kambing Boer, Kacang dan Boerka dan bersifat polimorfik yang diidentifikasi menggunakan metode PCR-Sequencing.
\end{abstract}

Kata Kunci: Gen BMP15, PCR-Sequencing, Prolifik, Keragaman Genetik, SNP

\section{ABSTRACT}

Batubara A, Elieser S, Sumantri C. 2016. Study of BMP15 gene polymorphism in Boer, Kacang, and Boerka goats. JITV 21(4): 224-230. DOI: http://dx.doi.org/10.14334/jitv.v21i4.1636

The bone morphogenetic protein 15 (BMP15) gene or commonly called FecX (fecundity chromosome X) is a gene that controls the prolific properties. This study was aimed to identify the mutation of BMP15 gene and to analyze its polymorphism in Boer, Kacang, and Boerka goats. The total of 50 female goat bloods were identified using PCR-Sequencing method, 17 Boer, 16 Kacang and 17 Boerka respectively. BMP15 gene amplification resulted fragment with the length of $141 \mathrm{bp}$. Genotyping of BMP15 gene produced three genotypes. Result showed that two polymorphic SNP were found from BMP15 gene analyzed by genotype frequency, allele frequency, heterozygosis, and equilibrium of genotype in all population by the Hardy-Weinberg equilibrium test $(\chi 2)$. Sequence analysis results of BMP15 gene showed that there were two mutation between adenine (A) and guanine $(\mathrm{G})$ bases and determination of genotype BMP15 gene produced three genotypes there were GG, GA and AA. In conclusion, there was mutation of BMP15 gene in Boer, Kacang and Boerka goats and genetic polymorphism were identified using PCR-Sequencing method.

Key Words: BMP15 Gene, PCR-Sequencing, Prolific, Genetic Polymorphism, SNP

\section{INTRODUCTION}

Goats spread in different region with different climates and evolved in isolation from each other over long periods of time due to various selective pressures and genetic drift. The main breeding of goats is determined by geographic position, morphological character and production performance. Because of environmental factors and varying selection of treatment, the rate of genetic change is very diverse (Rout et al. 2008). Kacang goat is a local goat species with the highest population level in Indonesia. It has a high fertility rate with the percentage of prolific properties respectively, namely twin $52.2 \%$ and triplets 2.6\% (Pamungkas et al. 2009). Boer goat is a good type of meat production and a famous meat purpose, excellent meat quality, great adaption, exceptional resistance to disease, high non-seasonal fertility and kidding percentage are known to have a fast growing rate compared to other goats breeds (Hua et al. 2009; Zhang et al. 2009; Haryono et al. 2011). Boerka goat is a population of superior goat breeding through crossbreeding Boer and Kacang under the Agricultural Research Program, The Ministry of Agriculture Indonesia with the composition genotype between Boer goat and Kacang are 50\% (Haryono et al. 2011). With reproduction rate found in Boer, Kacang and Boerka goat are 1,80;1,80 and 1.82, respectively (Elieser et al. 2012). 
Prolific trait is the reproductive trait or the ability to give birth to more than one lamb. The prolific trait of each individual goat varies due to genetic variation leading to an increase in ovulation rate and the number of litters (litter size). The number of lamb per birth determines the rate of increase in the population of goats (Hidayat et al. 2015). Identification of the genetic diversity of livestock is essential for the conservation of genetic resources and the development of more productive seedlings (Batubara et al. 2013). According to (Chu et al. 2007) patterns of gene control over prolific mechanisms indicate a difference between goat and sheep breads, but the prolific properties of goats and sheep are still controlled by the same gene, BMP15. The bone morphogenetic protein 15 (BMP15) gene or commonly called FecX (fecundity chromosome X) (Farhadi et al. 2013) is a gene that controls the prolific properties of various sheep types (Hidayat et al. 2015) and an $\mathrm{X}$ linked gene (Fec X locus) of sheep belonging to TGF $\beta$ family with the protein product of BMP15 are paracrine factor, stimulates follicle growth, granulosa cell proliferation and cell-survival signaling (Demars et al. 2013).

Many studies have shown that the importance of BMP15 gene in regulating ovarian function has spurred the extensive studies in several species including rodents, sheep and human. In goats, information for these studies still limited (Cui et al. 2009) especially for Boer goats, Kacang and crossbreeding B) are non.

BMP15 has got important in terms of booroola phenotype and also termed as GDF-9B genetic code for protein synthesis in oocytes which enhance the formation of follicles and fecundity of sheep and goat. Role of BMP15 genes is not known how it works to manage granulose cell (Jalbani et al. 2017). Recently, researchers argued that 5 mutations influence the prolificacy in BMP15 gene by expressing amino acid sequences $\left(\mathrm{vicFec}^{\mathrm{XL}}, \mathrm{Fec}^{\mathrm{XB}}, \mathrm{Fec}^{\mathrm{XI}}\right.$ ) or premature stop codons $\left(\mathrm{Fec}^{\mathrm{XG}}, \mathrm{Fec}^{\mathrm{XH}}\right.$ ) (Monteagudo et al. 2009) on ovulation rate are considerably improved in heterozygosis (Bodin et al. 2007).

The objective of this study was to identify the diversity of Bone Morphogenetic15 (BMP15) fecundity gene in Boer, Kacang and Boerka goats using PCRSequencing method and analyzing BMP15 gene polymorphism.

\section{MATERIALS AND METHODS}

\section{Sample sources}

The total numbers of goat used in this study were 50 samples derived from three populations with 17 Boer, 16 Kacang and 17 Boerka from Goats Research Station Sei Putih, North Sumatera, Indonesia, Indonesia. Blood sampling was done with a venoject needle on the jugular vein. The venoject needle was connected to the vacutainer tube containing EDTA. The required blood is $\pm 5 \mathrm{~mL}$ and stored at $\pm 4{ }^{\circ} \mathrm{C}$. Sample was analyzed for DNA extraction, DNA amplification and data analysis in Animal Molecular Genetics Laboratory, Faculty of Animal Science, Bogor Agricultural University.

\section{DNA extraction}

Genomic DNA was extracted from blood samples based on the modified PCR Bio systems Kit DNA extraction procedure. The first step was sample preparation as follow: $8 \mu \mathrm{l}$ of blood sample in $1.5 \mathrm{~mL}$ micro centrifuge tube and as much as $10 \mu \mathrm{l}$ x PCRBIO Rapid Extract Buffer A $(1 \mu 1 / \mathrm{mL})$ was added as lysis buffer. $10 \mu \mathrm{l}$ of 10x PCRBIO Rapid Extract Buffer B was added. A total of $70 \mu \mathrm{l}$ of PCR Grade $\mathrm{H}_{2} \mathrm{O}$ was added. Then homogenized with vortex. Samples were incubated at $75^{\circ} \mathrm{C}$ for 20 minutes and homogenized at every 5 minutes. And incubated back at $95^{\circ} \mathrm{C}$ for 15 minutes. Then $900 \mu \mathrm{l}$ of PCR Grade $\mathrm{H}_{2} \mathrm{O}$ was added. Conducted centrifuge at high speed, $13200 \mathrm{rpm}$ for 1 minute. Supernantan was taken and stored at $-20^{\circ} \mathrm{C}$.

\section{DNA amplification}

BMP15 gene fragment was amplified by PCR technique. The PCR was carried out in a reaction volume of $50 \mu \mathrm{L}$ containing $2 \mu \mathrm{L}$ genomic DNA template, $0.6 \mu \mathrm{L}$ primer of reverse and forward, $24.4 \mu \mathrm{L}$ nuclease free water, $25 \mu \mathrm{L}$ Master Mix (2x PCRBIO HS Taq Mix Red). Amplification was carried out with a thermal cycler machine GeneAmp® PCR System 9700 (Applied Bio system). The condition of thermal cycling consisted of predenaturation at $95^{\circ} \mathrm{C}$ for $5 \mathrm{~min}$, followed by 40 cycles of denaturation at $95^{\circ} \mathrm{C}$ for $15 \mathrm{~s}$, annealing at at $62^{\circ} \mathrm{C}$ for $15 \mathrm{~s}$ and extension at $72^{\circ} \mathrm{C}$ for $15 \mathrm{~s}$. The final extension step was at $72^{\circ} \mathrm{C}$ for $2 \mathrm{~min}$. The DNA amplification products were checked on $1.5 \%$ agarose gels in 0.5 TBE buffer containing with a $100 \mathrm{bp}$ ladder as a molecular weight marker.

\section{DNA sequencing and analysis}

PCR products representing different genotype of each gene were sequenced with DNA sequencer machine provided by DNA sequencing service in Macrogen-Korea. Sequence results were analyzed by BioEdit (Hall 1999) and sequence alignment was performed by MEGA software version 6.0 (Tamura et al. 2013) in order to find nucleotide mutation. The BLAST (Basic Local Alignment Search Tool) program was used to search the NCBI GenBank database for reference and homologous sequences. 
Table 1. Forward and reverse primer sequence for the amplification*

\begin{tabular}{lllc}
\hline \hline Gen & GenBank & Sekuens Primer & Product \\
\hline BMP15 & EU743938.1 & F: 5' CACTGTCTTCTTGTTACTGTATTTCAATGAC-3' & $141 \mathrm{bp}$ \\
& Kromosom X & R: 5'GATGCAATACTGCCTGCTTG 3' & \\
\hline
\end{tabular}

*Source: (Chu et al. 2007)

\section{Data analysis}

\section{Genotype and allele frequencies}

The genotype and allele frequencies as were described by (Nei \& Kumar 2000) were analyzed using genotyping data from each gene and calculated based on the populations of boer, kacang and boerka goats. Genotype frequency was calculated by the following formula:

$$
\mathrm{X}_{\mathrm{ii}}=\frac{x_{\mathrm{ii}}}{N}
$$

Allele frequency was calculated by the following formula:

$$
X_{i}=\frac{2 n_{i i i}+\sum n_{i j}}{2 N}
$$

Description:

$$
\begin{aligned}
& \mathrm{X}_{\mathrm{ii}}=\mathrm{ii}^{\text {th }} \text { genotype frequency } \\
& \mathrm{X}_{\mathrm{i}}=\mathrm{i}^{\text {th }} \text { allele frequency } \\
& \mathrm{n}_{\mathrm{ii}}=\text { Number of sample of } \mathrm{ii} \text { genotype } \\
& \mathrm{n}_{\mathrm{ij}}=\text { Number of sample of } \mathrm{ij} \text { genotype } \\
& \mathrm{N}=\text { Total samples }
\end{aligned}
$$

\section{Heterozygosis}

Observed heterozygosis (Weir 1996) and expected heterozygosis (Nei \& Kumar 2000) were tested by the following formula:

$$
\begin{gathered}
\mathrm{H}_{\mathrm{o}}=\sum_{i \neq j} \frac{n_{i j}}{N} \\
\mathrm{H}_{\mathrm{e}}=1-\sum_{i=1}^{q} x_{i}{ }^{2}
\end{gathered}
$$

Description:

$$
\begin{aligned}
& \mathrm{H}_{\mathrm{o}}=\text { Observed heterozygosis } \\
& \mathrm{n}_{\mathrm{ij}}=\text { Number of heterozygous animal } \\
& \mathrm{N}=\text { Number of observed animal } \\
& \mathrm{H}_{\mathrm{e}}=\text { Expected heterozygosis } \\
& \mathrm{X}_{\mathrm{i}}=\text { Frequency of allele } \\
& \mathrm{Q}=\text { Total allele }
\end{aligned}
$$

\section{Hardy-Weinberg equilibrium}

Test of Hardy-Weinberg equilibrium (HWE) was conducted with chi-square test (Kaps \& Lamberson 2004).

$$
\chi^{2}=\sum \frac{(o b s-\theta x p)^{2}}{\exp }
$$

Description:

$\chi^{2}=$ Hardy-Weinberg equilibrium test

obs $=$ Observed number of it $^{\text {th }}$ genotype

$\exp =$ Expected number of ii $^{\text {th }}$ genotype

The number of degrees of freedom (df) is equal to the number of possible genotypes minus the number of (Allendorf et al. 2013) or as describe below:

$\mathrm{df}=\left(\right.$ number of $\mathrm{ii}^{\text {th }}$ genotype $)-\left(\right.$ number of $\mathrm{j}^{\text {th }}$ allele $)$

\section{RESULTS AND DISCUSSION}

\section{Genetic polymorphism of the BMP15 gene}

BMP15 gene fragments were successfully amplified by polymerase chain reaction technique for all samples. Amplification was successfully performed on the BMP15 gene with annealing temperature of $62^{\circ} \mathrm{C} 15$ seconds and yielded a product of $141 \mathrm{bp}$ while according to (Hidayat et al. 2015) the annealing temperature is $63^{\circ} \mathrm{C} 45$ seconds. The success of the amplification is dependent heavily on the annealing temperature. The annealing temperature is the optimum temperature for the primer attachment process according to the target DNA sequence to be propagated during the PCR process. This difference is caused by the condition of the PCR machine and the mixture of PCR reagents. The primer attenuation temperature (annealing) ranges from $36-72^{\circ} \mathrm{C}$, but the usual temperature is $50-60^{\circ} \mathrm{C}$ (Muladno 2002). According to (Pelt-Verkuil et al. 2008) the annealing time required for the primer to be complementary and adhered to its target depending on the thermo cycler machine's 
heating capacity used, the PCR mixed volume as well as the primer and targeted gene concentrations. Primer that has been attached to the next target undergoes elongation or extension at $72^{\circ} \mathrm{C}$ for 15 seconds. Then proceed with the final elongation at the same temperature for 2 minutes. The three stages of PCR are denaturation, annealing and elongation are the stages for 1 thermal cycle. In this study 40 cycle was done.

\section{Homology and detection of mutation gene BMP15}

The results of BMP15 gene sequence and alignment sequence with GenBank (access code EU74393.1) using forward and reverse primer pair indicated that the genotype frequency of BMP15 gene based on Boer goat, Kacang of samples was found by two SNP, SNP c. $38 \mathrm{~A}>\mathrm{G}, \mathrm{SNP}$ c. $49 \mathrm{G}>\mathrm{A}$.

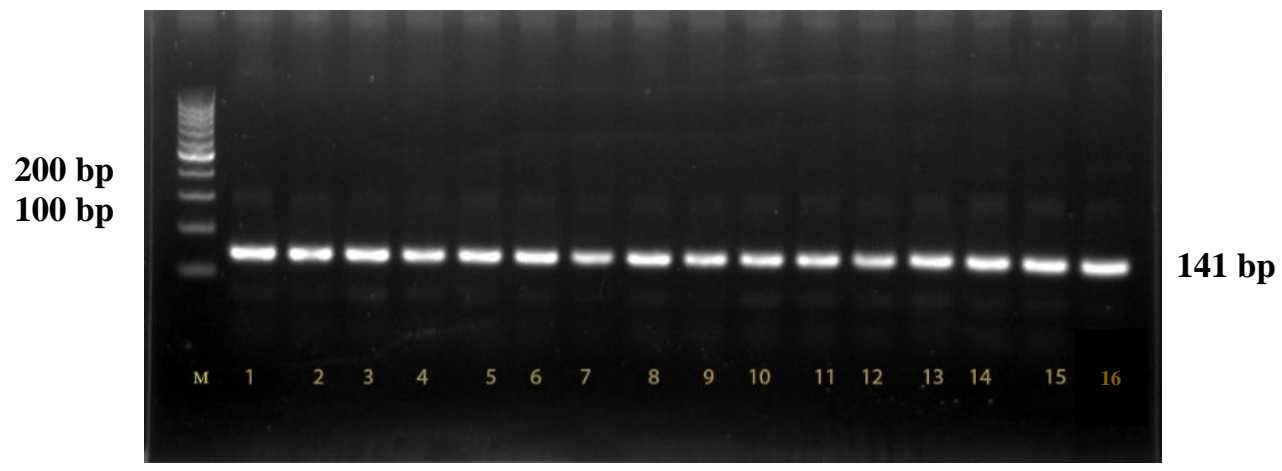

Figure 1. Visualization of PCR product amplified from Boer (1-5), Kacang (6-10), Boerka goat (11-16) samples (141 bp)

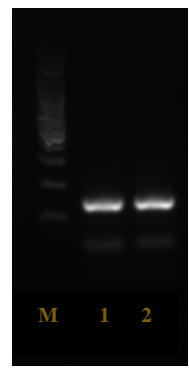

$141 \mathrm{bp}$

Figure 2. Visualization of PCR product amplified with annealing temperature of $62^{\circ} \mathrm{C} 15$ seconds and yielded a product of $141 \mathrm{bp}$ while according to (Hidayat et al. 2015) from Boer (1) and Boerka (2) samples (141 bp).

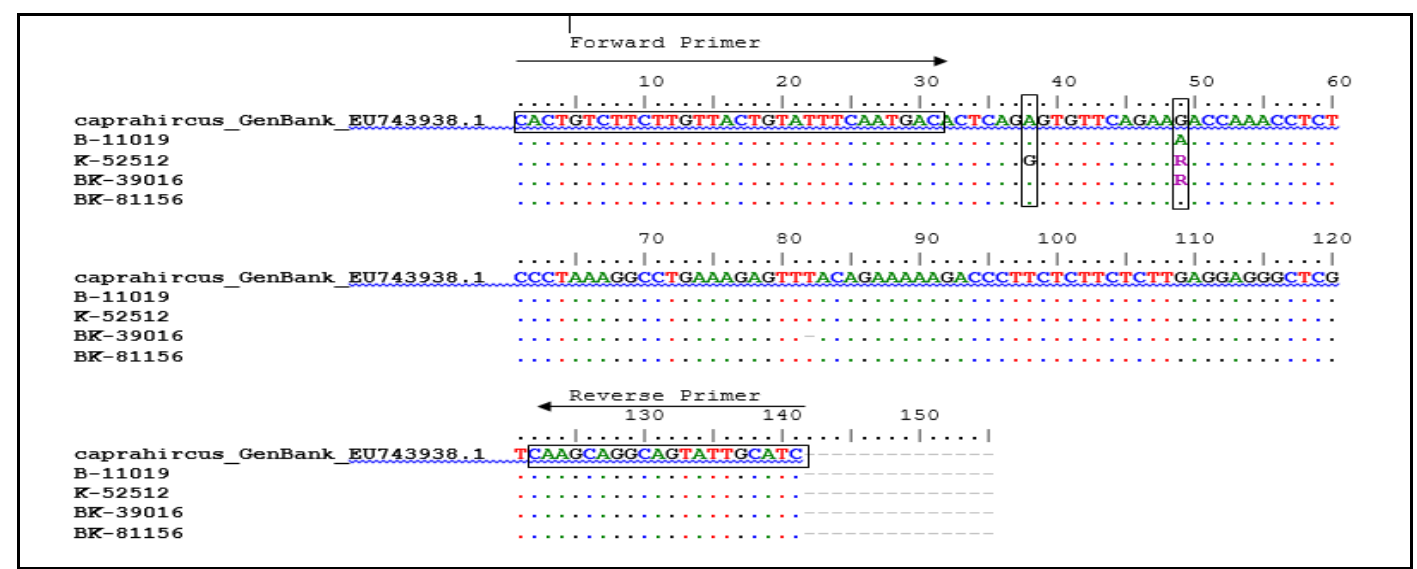

Figure 3. Nucleotide sequences alignment result of BMP15 gene. GenBank of BMP15 sequences (accession number EU 743938.1) were used for reference to find nucleotide mutation. $=$ homologous sequences. 


\section{Genotype frequency and frequency of Allele of BMP15 fragment}

The result of genotype frequency on SNP found in Table 2 explained that the genotype frequency of BMP15 gene based on samples of Boer, Kacang and Boerka goats used in this study yields three genotypes found is genotype GG, GA and AA. The genotype for Boer goat found in BMP15 SNP c.49 gene were GG, GA and AA with genotype frequency of $0.471 ; 0.235$ and 0.294. Genotypes for Kacang goat found in BMP15 SNP c.49 gene were GG, GA and AA with genotype frequency of $0.125 ; 0.438$ and 0.438 . The genotypes for Boer goat found in BMP15 SNP c.49 gene were GG, GA and AA with genotype frequencies of $0.235 ; 0.235$ and 0.529 . SNP is said to be polymorphic if it has an allele frequency of $\leq 0.99$ for large populations and $\leq 0.95$ for a smaller population (Allendorf et al. 2013). So it can be said that BMP15 gene in boer, kacang and boerka goats.

In previous study of BMP15 gene in another goat breed, (Chu et al. 2007) found two genotypes: AA and $\mathrm{AB}$ in Jining Gery goats. Genotype AA was found in low fecundity goat breeds and AB genotype had 1.3 kids more than homozygous AA. In another study on different goat breeds, Feng et al. (2009) found three genotypes AA, AG and GG in Jining Grey goats, and only AA genotype was found in both Liaoning Cashmere and Inner Mongolia Cashmere goats. Boer goat found two genotypes AG and GG, while only AA genotype in both Angora and Inner Mongolia Cashmere goats. In a recent study of Wang et al. (2011), three genotypes (AA, BB and $\mathrm{AB}$ ) were detected in Funiu White goats and their frequency was $0.071,0.715$ and 0.214 , respectively. Two genotypes (AB and $\mathrm{BB}$ ) were detected in Taihang black goats and their frequency was 0.342 and 0.658 , respectively. The Funiu white goat with genotype $\mathrm{BB}$ had 0.91 or 0.82 kids more than those with $\mathrm{AB}$ or $\mathrm{AA}$, respectively. However, these results preliminarily showed that BMP-15 gene is a genetic marker and closely linkage to the litter size trait and consequently, can be used as a marker-assisted selection (MAS) for high litter size productivity in goat (Abdel-Rahman et al. 2013). The genotype frequency shows the ratio of the number of genotypes to a population by computing the ratio between the numbers of specific genotypes in each population whereas the allele frequency is the ratio of an allele to the overall allele to an SNP in the population (Noor 2010). SNP is said to be polymorphic if it has an allele frequency of $\leq 0.99$ for large populations and $\leq 0.95$ for a smaller population (Allendorf et al. 2013).

\section{Heterozygosis and Hardy-Weinberg equilibrium}

The result of $\mathrm{Ho}$ and $\mathrm{He}$ test showed that the observed heterozygosis (Ho) does not differ greatly from the heterozygosis of expectation (He). Tombasco et al. (2013) states that if the value of Ho (Heterozygosis observation) is lower than $\mathrm{He}$ (Heterozygosis expectation) then it may indicate an intensive selection process. According to Tambasco et al. (2013) the difference between the observed heterozygosis value $(\mathrm{Ho})$ and heterozygosis $(\mathrm{He})$ can be used as an indicator of the presence of genotype imbalance in the observed Boer goats, Kacang and Boerka population indicated that there is already a selection activity performed and the absence of random marriage.

The observed heterozygosis value $(\mathrm{Ho})$ of the BMP15 gene was found in SNP c.49G>A in Boer, Kacang and Boerka goats respectively of 0.235 ; 0.438 and 0.235 . For the highest heterozygosis value is on SNP c.49G>A of Kacang goats is 0.438. The heterozygosis value of SNP BMP15 gene is presented in Table 3. Marson et al. (2005) suggest that the genetic diversity of a population can be measured using heterozygosis values aimed at assisting the selection program. Heterozygosis expresses the genetic diversity of a population that can be used for selection programs. Noor (2010) explains that gene diversity can be used as a reference in determining breeding programs that are selected if diverse populations and crosses are performed when the population is uniform. An SNP is said to have high diversity if the heterozygosis value $>0.50$ (Allendorf et al. 2013).

Table 2. Allelic and genotypic frequencies values of BMP15 in Boer, Kacang and Boerka goats

\begin{tabular}{lccccc}
\hline \hline \multirow{2}{*}{ Goats } & \multicolumn{3}{c}{ Genotype frequency } & \multicolumn{2}{c}{ Allele frequency } \\
\cline { 2 - 6 } & GG & GA & AA & G & A \\
\hline Boer & 0.471 & 0.235 & 0.294 & 0.588 & 0.412 \\
Kacang & 0.125 & 0.438 & 0.438 & 0.344 & 0.656 \\
Boerka & 0.235 & 0.235 & 0.529 & 0.353 & 0.647 \\
\hline
\end{tabular}


Table 3. Heterozygosis and Hardy-Weinberg equilibrium (HWE) value

\begin{tabular}{|c|c|c|c|c|c|c|c|}
\hline \multirow{2}{*}{ Goats } & \multirow{2}{*}{ Number of samples } & \multicolumn{3}{|c|}{ Total goats } & \multirow{2}{*}{$\mathrm{He}$} & \multirow{2}{*}{ Ho } & \multirow{2}{*}{$X^{2}$} \\
\hline & & GG & GA & AA & & & \\
\hline Boer & 17 & 8 & 4 & 5 & 0.484 & 0.235 & 4.496 \\
\hline Kacang & 16 & 2 & 7 & 7 & 0.451 & 0.438 & 0.015 \\
\hline Boerka & 17 & 4 & 4 & 9 & 0.457 & 0.235 & 3.996 \\
\hline
\end{tabular}

The balance of population can be seen through the Hardy-Weinberg Equilibrium presented in Table 2. The result show that BMP15 gene on SNP c.49G>A is in a balanced state. Factor affecting the balance in a population are non-random mating, selection, migration, mutation and genetic driff (Noor 2010).

\section{CONCLUSION}

In conclusion, the present study of BMP15 gene in Boer, Kacang, and Boerka are polymorphic. Two polymorphic SNP and three genotypes GG, GA, and AA were found with allele frequency of $G$ and $A$ are $<0.99$. Sequence analysis results confirm mutation $\mathrm{A} \rightarrow \mathrm{G}$ and $\mathrm{G} \rightarrow \mathrm{A}$ base in BMP15 gene.

\section{ACKNOWLEDGEMENT}

Authors were grateful to Arie Febretrisiana, Silvia Nova and Animal Molecular Genetics Laboratory, Faculty of Animal Science, Bogor Agricultural University for helps during this research. This research was funded by Government Budget of Goats Research Station, Sei Putih in 2016.

\section{REFERENCES}

Abdel-Rahman SM, Mustafa YA, Abd Errasool HA, ElHanafy AA, Elmaghraby AM. 2013. Polymorphism in BPM-15 gene and its association with litter size in Anglo-Nubian goat. Biotechnol Anim Husb. 29:675683.

Allendorf FW, Luikart GH, Aitken SN. 2013. Conservation and the genetics of populations. 2nd ed. UK: WileyBlackwell.

Batubara A, Rr N, Farajallah A, Tiesnamurti B. 2013. Keragaman genetik DNA Y-Kromosom pada enam rumpun kambing lokal Indonesia. Nurhayati D. Purwantari, Muharam Saepulloh, Sofjan Iskandar, Anneke Anggraeni, Simon P. Ginting, Atien Priyanti, Ening Wiedosari, Dwi Yulistiani, Ismeth Inounu, Sjamsul Bahri, Wisri Puastuti. Prosiding Seminar Nasional Teknologi Peternakan dan Vet. 4:316-325

Bodin A, Ahrenstedt L, Fink H, Brumer H, Risberg B, Gatenholm P. 2007. Modification of nanocellulose with a xyloglucan-rgd conjugate enhances adhesion and proliferation of endothelial cells: Implications for tissue engineering. Biomacromolecules. 8:3697-3704.

Chu MX, Jiao CL, He YQ, Wang JY, Liu ZH, Chen GH. 2007. Association between PCR-SSCP of bone morphogenetic protein 15 gene and prolificacy in Jining Grey Goats. Anim Biotechnol. 18:263-274.

Chu MX, Liu ZH, Jiao CL, He YQ, Fang L, Ye SC, Chen GH, Wang JY. 2007. Mutations in BMPR-IB and BMP-15 genes are associated with litter size in Small Tailed Han sheep (Ovis aries). J Anim Sci. 85:598-603.

Cui H, Ghosh SK, Jayaram M. 2009. The selfish yeast plasmid uses the nuclear motor Kip1p but not Cin8p for its localization and equal segregation. J Cell Biol 185:251-264.

Demars J, Fabre S, Sarry J, Rossetti R, Gilbert H, Persani L, Tosser-klopp G, Mulsant P, Nowak Z, Drobik W, et al. 2013. Genome-wide association studies Identify two novel BMP15 mutations responsible for an atypical hyperprolificacy phenotype in sheep. LoS Genet 9:e1003482. doi: 10.1371/journal.pgen.1003482

Elieser S, Sumadi, GS, Subandriyo. 2012. Kinerja reproduksi induk kambing Boer, Kacang dan Boerka. JITV 17:100106.

Farhadi P, Soosani J, Adeli K, Alijani V. 2013. The effect of destruction in positioning of Quercus brantii in Zagros forests, Iran. J Biodiversity Environment Sci. 3:49-57.

Feng W, Bachant J, Collingwood D, Raghuraman MK, Brewer BJ. 2009. Centromere replication timing determines different forms of genomic instability in Saccharomyces cerevisiae checkpoint mutants during replication stress. Genetics. 183:1249-1260.

Hall T. 1999. BioEdit: a user-friendly biological sequence alignment editor and analysis program for Windows 95/98/NT. Nucleic Acids Symp Ser. 41:95-98.

Haryono, Tiesnamurti B, Setiadi B, Ginting SP, Talib C. 2011. Superior breeds of small ruminant produced by Agricultural Agency of Research and Development (AARD). Simon P. Ginting, Aron Batubara, Rasali Hakim Matondang, Tati Herawati, Rini Damayanti, Umi Adiati, Chalid Talib. Proceeding of Workshop Nasional Diversifikasi Pangan Daging Ruminansia Kecil. Kota (Indones): Indonesian Agency of Agricultural Research and Development. p. 3-16. 
Hidayat RA, Depamede SN, Maskur. 2015. Identification of mutation on gene FecX BMP15 and its effects on prolific nature of local goats in West Lombok Regency. J Ilmu Teknol Peternakan Indones. 1:1-7.

Hua GH, Chen SL, Yu JN, Cai KL, Wu CJ, Li QL, Zhang CY, Liang AX, Han L, Geng LY, et al. 2009. Polymorphism of the growth hormone gene and its association with growth traits in Boer goat bucks. Meat Sci. 81:391-395.

Jalbani MA, Kaleri HA, Baloch AH, Bangulzai N, Bugti AG, Ashraf F, Kaleri RR, Jan M, Bugti GA, Khosa AN 2017. Study of BMP15 gene polymorphisim in Lehri goat breed of Balochistan. J Appl Environment Biol Sci. 7:84-89.

Kaps M, Lamberson WR. 2004. Biostatistics for animal science. UK: CABI Publishing. doi: 10.1111/j.14390388.2005.00495.X

Marson A, Jacoby A, Johnson A, Kim L, Gamble C, Chadwick D. 2005. Immediate versus deferred antiepileptic drug treatment for early epilepsy and single seizures: a randomised controlled trial. The Lancet. 365:2007-2013.

Monteagudo LV, Ponz R, Tejedor MT, Lavina A, Sierra I 2009. A $17 \mathrm{bp}$ deletion in the bone morphogenetic protein 15 (BMP15) gene is associated to increased prolificacy in the Rasa Aragonesa sheep breed. Anim Reprod Sci. 110:139-146.

Muladno. 2002. Teknik rekayasa genetika. Bogor (Indones): Pustaka Wirausaha Muda
Nei M, Kumar S. 2000. Molecular evolution and phylogenetics. New York (USA): Oxford University Press.

Noor RR. 2010. Genetika ternak. Jakarta (Indones): Penebar Swadaya.

Pamungkas FA, Batubara A, Doloksaribu M, Sihite E. 2009. Potensi plasma nutfah kambing lokal Indonesia. Pamungkas FA, editor. Bogor (Indones): IAARD Press..

Pelt-Verkuil EV, Belkum AV, Hays JP. 2008. Principles and technical aspects of PCR amplification. AZ Dordrecht (Netherland): Springer, Dordrecht.

Rout PK, Joshi MB, Mandal A, Laloe D, Singh L, Thangaraj K. 2008. Microsatellite-based phylogeny of Indian domestic goats. BioMeds Central Genet. 9:11.

Tamura K, Stecher G, Peterson D, Filipski A, Kumar S. 2013. MEGA6: Molecular evolutionary genetics analysis version 6.0. Mol Biol Evol. 30:2725-2729.

Wang Y, Yuanxiao L, Nana Z, Zhanbin W, Junyan B. Polymorphism of exon 2 of BMP15 gene and its relationship with litter size of two Chinese goats. AsianAust J Anim Sci. 24:905-911.

Weir BS. 1996. Genetic data analysis ii methods for discrete population genetic data. Sunderland, Massachusetts: Sinauer Associates, Inc. Publishers.

Zhang C, Zhang Y, Xu D, Li X, Su J, Yang L. 2009. Genetic and phenotypic parameter estimates for growth traits in Boer goat. Livest Sci. 124:66-71. 